\title{
THE PQRST STRATEGY, READING COMPREHENSION, AND LEARNING STYLES
}

\author{
Alfi Hidayatu Miqawati \\ Faculty of Political and Social Sciences, University of Bondowoso, East Java \\ email: alfi_hidayah@yahoo.com \\ Gunadi Harry Sulistyo \\ Faculty of Letters, State University of Malang, East Java \\ email: emailgun.now@gmail.com
}

\begin{abstract}
This study aims at investigating the effectiveness of the PQRST strategy in students' reading comprehension, the effectiveness of the PQRST strategy in reading comprehension of students with different learning styles, and the interaction between the PQRST strategy and the students' learning styles. This study employed a $2 \times 2$ factorial design. The subjects were the second semester students of Public Administration Department, Faculty of Political and Social Science, University of Bondowoso. Two classes were randomly selected as the samples of this study. The experimental class was taught by using the PQRST strategy and the non-experimental class by translation and reading aloud. The data were analysed by utilizing non parametric testing: Mann-Whitney $U$ and Kruskall-Wallis. The findings showed that the PQRST strategy statistically impacted students' reading comprehension compared to the one taught using the translation and reading aloud. But, it was revealed that there was no difference in the reading comprehension of students with different learning styles taught under the PQRST strategy and translation and reading aloud, and there was no interaction between teaching strategies and students' learning styles.
\end{abstract}

Keywords: PQRST, learning styles, reading comprehension

\section{STRATEGI PQRST, MEMBACA PEMAHAMAN, DAN GAYA BELAJAR}

\begin{abstract}
Abstrak: Penelitian ini bertujuan untuk meneliti keefektifan strategi PQRST terhadap membaca pemahaman siswa, keefektifan strategi PQRST terhadap membaca pemahaman siswa dengan beragam gaya belajar, dan interaksi antara strategi PQRST dan gaya belajar siswa. Penelitian ini menerapkan desain faktorial 2x2. Para partisipan penelitian adalah mahasiswa semester 2 jurusan Administrasi Umum, Fakultas Ilmu Sosial dan Ilmu Politik, Universitas Bondowoso. Dua kelas dipilih secara acak sebagai sampel penelitian. Strategi PQRST diajarkan di kelas eksperimen, sementara strategi menerjemahkan dan membaca keras diajarkan di kelas non-eksperimen. Data kemudian dianalisis menggunakan uji non-parametrik, yakni Mann-Whitney U dan KruskallWallis. Hasil penelitian menunjukkan bahwa strategi PQRST secara statistik mempengaruhi membaca pemahaman dibandingkan strategi menerjemahkan dan membaca keras. Namun, tidak ditemukan perbedaan antara membaca pemahaman siswa dengan gaya belajar, baik di kelas yang diajari strategi PQRST maupun strategi menerjemahkan dan membaca keras. Selain itu, tidak ditemukan interaksi antara strategi mengajar dan gaya belajar siswa.
\end{abstract}

Katakunci: PQRST, gaya belajar, membaca pemahaman

The effectiveness of the teaching of English to non-English department students at the college level has largely been questioned. As indicated by the findings of 
a study by Winarni, et al. (2005), most graduates of non-English departments were low in their English proficiency and belonged to the elementary level category. The condition is even worsened by the fact that most students are not serious in taking the course and they are not motivated to learn English. They consider English as a non main subject so that English is considered less important. They can pass the subject examination without knowledge of English (Robinson, 1991). More elaborately, a study conducted by Sulistyo (2012:128-129) reveals that college students' mastery in their reading comprehension seen from their origin of institutions-private or public universitiesand the students' major-social or natural sciences-have a significant difference. More surprisingly, it is also revealed that the students on the average have low abilities in comprehending detailed information of various academic texts, identifying meanings seen from different sentence structures, and comprehending meanings through text structure attack skills, the reading skills of which have been the focus of six years' previous teaching English in both the lower and the higher secondary levels of education accumulatively.

Beside empirical problems faced by the students described previously, the ESP lecturers as well as ESP teachers also experience difficulties in delivering their instructional materials to their students. According to Hutchinson \& Waters (1987:158), three problems are identified, which matches the results of discussions with teachers of ESP. These are lack of ESP orthodoxy to provide a ready-made guide, the new realm of knowledge the ESP teachers have to cope with, and the change in the status of English language teaching. It is believed that these challenges inevitably lead to practical problems encountered by the students in their learning English. With these issues as practical and empirical evidence, if optimum learning is sought in the practices of teaching ESP, essentially the teaching of ESP needs to shift its focus from English in isolation to English as medium for subject matter exchanges (Aniroh, 2009:169). With this teaching orientation, both students and ESP lecturers will obviously have a clear picture of what to learn and how to learn ESP at college levels.

At the conceptual level, Hutchinson \& Waters (1987:16) note that ESP is divided into two main types and differentiated according to whether the learner requires English for academic study (EAP: English for Academic Purposes) or for work/training (EOP/EVP/VESL: English for Occupational Purposes/English for Vocational Purposes/Vocational English as a Second Language). As Sulistyo (2012:130) asserts, in the Indonesian context essentially the teaching of English to college students of non-English departments, in which English as a course is only offered in one semester with 2 credits semester, needs to be classified into EAP since it aims to equip the students with academic reading study skills. It is different from the purpose of the teaching of EOP of which orientation is to equip the students with English competences related to their specific field of study for future occupational purposes. With this view, one essential point to note is that the ESP course certainly need to have clear relevances to the students' academic and occupational immediate needs, can improve their motivation to learn, and shows significant effectiveness in making learning English better and faster.

All in all, in the context of the teaching of reading to non-English department students who take EAP course, it is obvious that the students are expected to be able to convey implicit and explicit details from various texts they read. However, several studies revealed that the reading ability of many non-English department students was still inadequate. One of them is a study conducted by Baker (1985) as 
cited by Fahim (2012:141) who found that college students with lower verbal abilities were able to identify individual words and facts but were unable to combine the information in the text with the previously acquired information. This inability to integrate ideas was accompanied by an inability to draw logical inferences and to check ideas while reading to see if the ideas contradict each other. Since reading comprehension plays a central role in academic instruction and it is what the students need to succeed both in an academic environment and real-life situations or occupational matters later, it seems necessary to provide explicit training in the specific reading strategy skills in which students are expected to demonstrate adequate proficiency in reading.

At the Public Administration Department, Faculty of Political and Social Science, University of Bondowoso, an EAP course-Bahasa Inggris 1 -is offered in semester two with two credits. An interview with three ESP lecturers was conducted to gain information on the teaching of EAP in the department. They mentioned that when teaching, they delivered a text to the students and asked them to read sentence per sentence and to translate word by word or sentence per sentence. Also, the students were asked to report when they found difficulties in the grammar constuctions of the sentences and the meaning of words for comprehending the reading passages. They also added that most of the time, they taught English in the students' native language, Bahasa Indonesia. Taber (2006) states that translation of literary passages from the target language into the native language constitutes one feature of the GrammarTranslation Method. The classical procedure for intensive reading utilized in the department is certainly close to the practice of the Grammar-Translation Approach in which the teacher works with the learners, using the first language to explain the meaning of a text, sentence by sentence. The use of translation is believed that that learners will understand, and when the learners do some of the translation themselves, it allows the teacher to check whether they understand (Nation, 2008:25). Sulistyo (2011:24) asserts that ability to translate word by word of a passage is no warranty of abilities to comprehend the passage content as a whole.

Wilson (2010) defines that when students are asked to read a reading passage in a course book line by line, it is called reading aloud. Intensive work on a reading text may focus on several aspects, one of which is regular and irregular sound-spelling relations which can be done through reading aloud (Nation, 2008:27). Reading aloud has not been looked on very favorably in the second language reading class, mainly because of the misuse of the technique around the class. However, in the first language classroom, reading aloud is a very important step to gain fluent decoding and comprehending skills. Reading aloud has as much value in the second language class as in the first (Nation, 2008:66-67).

The three lecturers at the Public Administration Department, Faculty of Political and Social Science, University of Bondowoso employed this kind of strategy for several reasons. First, they said that the students' English low proficiency and low motivation made it difficult for them to comprehend a text, let alone academic ones. Second, they thought that translation and reading aloud can facilitate the students' learning process since it can accommodate a big class comprising of 3545 students in learning and invite them to participate and pay adequate attention. Third, they mentioned that they had limited time to teach, which is only 100 minutes per week. By applying this strategy, they could save the time. This is in line with what Hamra \& Syatriana (2010:31) remark about teaching skilled and unskilled readers. They argue that skilled and unskilled readers recognize words 
differently. In reading comprehension, an unskilled reader may be helped by saying the words loudly. Meanwhile, Wilson (2006) and Ronald (2012) oppose the use of reading aloud in the teaching of reading comprehension. They note that reading aloud has drawbacks in these areas. It does not bring the text to life, limits reading speed and habit, and is only useful in initially developing basic reading skills but can be an obstacle to reading faster. Certainly, reading aloud is not for comprehension purposes (Sulistyo, 2011).

Reading comprehension can be improved by employing certain strategies in the form of study skills. One of the widely used study strategies to gain students' comprehension especially in content area reading is PQRST, which stands for Preview, Question, Read, Summarize, and Test (Ahuja \& Ahuja, 2007:21). PQRST is an instructional strategy that has been shown to be effective to improve a reader's understanding, and his/her ability to recall information. In other words, the reader is more likely to learn, and to learn more, of the material he/she is reading. Steps in PQRST are also beneficial for aiding the students in comprehending a text. This strategy is also suitable for teaching expository reading which EAP students learn (Wormeli, 2005:131). The PQRST strategy has been empirically shown to be able to improve students' reading comprehension. Haeriyanto (2012) conducted classroom action research (CAR) and found out that the PQRST strategy could improve the reading comprehension skills of the eleventh graders.

However, the success of second language learning is affected by a host of interrelated factors (Sulistyo, 2011). It is due not only to cognitive factors but also to affective factors of the learners (Brown, 2007:152), some of which are intelligence, aptitude, personality, motivation and attitude, learning style, and age of acquisition (Lightbrown \& Spada,
1993:36-41). In relation to cognitive and affective factors, learning strategies and learning styles are often seen as interrelated. Brown (1991) cited in Cohen (1996:10) notes that learning strategies do not operate by themselves, but rather are directly tied to the learner's underlying learning styles (i.e., general approaches to learning) and other personality-related variables (such as anxiety and self-concept) in the learner. It is supported by Oxford (2003:315) who mentions that styles are made manifest by learning strategies.

To outline an overall picture of learning styles, Reid (1995) as cited in Sadeghi et al. (2012:117) presents a comprehensive and categorical framework of learning styles; they have been divided into three major categories: cognitive learning styles, sensory learning styles, and personality learning styles. Cognitive learning styles include field-independent vs. field-dependent; analytic vs. global; and reflective vs. impulsive. Sensory learning styles may be divided into two other subcategories: perceptual learning styles: auditory learner, visual learner, tactile learner, kinesthetic learner, and haptic learner; environmental learning styles: physical vs. sociological learner. Personality learning styles comprise extroversion vs. introversion; sensing vs. intuitive; thinking vs. feeling; judging vs. perceiving learners.

Learning styles in this study deals with the personality learning styles and are specified into two: sensing and intuitive. Marrapodi, (2004:7) defines sensing learners are practical, are interested in facts and details, and like direct and concrete experience while intuitive learners are "holistic" learners who are interested in possibilities and want to explore concepts, ideas and abstractions. Unlike sensing learners who need a practice-to-theory model to succeed, and often need to know what to expect before doing something, intuitive learners are good at grasping concepts and want to deal with the 
imaginative possibilities rather than on concrete realities.

There is abundant evidence on how successful learners with sensing learning style and those with intuitive learning achieve their learning. For example, Ehrman and Oxford (1990) found that students with sensing learning styles have the most difficulty with learning compared to the intuitive ones. They concluded that intuitive ones seemed to have a learning advantage in the classroom and they are better readers. Meanwhile, sensing types were poor in both reading and speaking. Meanwhile, a different study conducted by Pfister (2000) showed an opposite finding. The result of her study showed that intuitive learners did not achieve well even being outperformed by sensing students.

The results of the findings these studies are then not as comprehensive and congruent as they are supposed to be, i.e. one cannot conclude which type(s) of personality contribute more to reading comprehension. While conceptually it cannot be ignored the importance of predicting students' performance in reading comprehension and detecting their reading disabilities, dominant affective variables like personality have not beeen taken into serious considerations together with the other cognitive and non-cognitive variables (Sadeghi, et.al., 2012:121). Therefore, it is logical to state that more empirical studies to find more conclusive results in personality and reading comprehension research are still of the need, interest, and importance.

All in all, it is important to gain a deeper analysis on the effectiveness of certain strategies toward particular learning styles so that learners can be optimally facilitated and promoted in learning. There is a compelling need to make a thorough investigation through the effectiveness of the PQRST strategy on the teaching of reading students of non-English departments as there have been inconclusive findings in research in this area so far, especially in the context of English Language Teaching (ELT) for college students of non-English departments in Indonesia. Thus, this present study aims at examining the effectiveness of PQRST in college students' reading comprehension, especially those students with different personality learning styles, in particular sensing and intuitive, and any interaction between teaching strategies and students' personality learning styles.

\section{METHOD}

This study was experimental with a posttest only design. The design employed in the present study is called a two-by-two factorial design as the active variables under study were the PQRST strategy and translation and reading aloud. In addition, students' different personality learning styles, sensing and intuitive, are postioned as the attribute independent variables or factors. The dependent variable was the students' reading comprehension.

The subjects were the second semester students of Public Administration Department, Faculty of Political and Social Science, University of Bondowoso. The samples of this study were Class A1 and B1 selected randomly with Class A1 taught by using the PQRST strategy and B1 by translation and reading aloud. Class A1 consisted of 21 students and B1 consisted of 20 students. To show that the classes were homogeneous, a homogeneity test on the scores of the English entrance test was conducted. The result showed that the observed significance level was .068. Since the significance level that the researchers used was .05 and the observed significance level was higher than the level of confidence (Sig. .068 > Sig. .05), it showed that the data from the groups' variances were not homogeneous.

The experiment was carried out in eight meetings based on the consideration that not only the PQRST strategy was relatively new for the students so that they 
had to be accutstomed to the strategy before the researchers measured the effectiveness of the strategy, but also experimental treatments in eight sessions were considered sufficient to have the impact on students' comprehension. Both groups were taught on the same day, one after another. Threats to internal validity caused by time of implementation (history) could be minimized because the possibilities of interaction between groups were minimized. The lesson plans used for both groups were designed by the researchers. Both groups also had the same materials which were carefully selected. The reading passages were taken from several sources, such as books and the Internet reliable sources. There were seven different reading passages with various text types related to politics and social studies.

Both groups followed the prepared schedule for the implementation without awareness that experimental treatments were being employed. In this study, the researchers taught the experimental group using the PQRST strategy and a lecturer of Bahasa Inggris 1 taught the control group using Translation and Reading Aloud strategy. The researchers taught the experimental group for two reasons. The first reason was that the researchers was the one who knew the strategy as well as its implementation thus the researchers could confidently conclude that the result obtained was definitely caused by the strategy. The second was because the researchers had limited time to train other lecturers. Training other lecturers took some time so it is the constraints in this study. After being given the treatment as designed, the two groups were post-tested.

There were two instruments applied in this study: a reading comprehension test (for posttest) and a set of questionnaires. The instruments were used to collect the primary and the secondary data. The first instrument, a reading comprehension test, served as the primary instrument and was constructed to measure the students' reading comprehension after the treatment. The students' personality learning style questionnaire was the secondary instruments of this study. The students' personality learning style questionnaire was constructed to classify the students into two different personality learning styles: sensing learning style and intuitive learning style.

Before devising the instruments, the researchers validated the instrument to three experts, one language assessment expert and two reading experts, to ensure the content validity of the reading comprehension test, and tried out the instruments. The try-out administration was intended to know the item difficulty, item discrimination, item validity, distracter effectiveness and the reliability of the test. Based on the result of the tryout test, it was found out that the reliability coefficient of the reading comprehension test was .722, showing that the instrument was considered sufficiently dependable as an instrument to collect data.

The questionnaire for students' personality learning style was aimed at finding out whether or not the students were categorized into sensing and intuitive learning styles. The questionnaire was adapted from Index of Learning Styles Questionnaire (ILS) by Soloman (Felder \& Soloman, 1991). The questionnaire was adapted for its appropriateness of the content, easier calculation, and practicability. The questionnaire was adapted from the test sheet constructed and designed by Soloman and had been shown to be reliable $(r=.705)$. Since the questionnaire covered questions related to many learning styles, the researchers selected several points in the test related to two learning styles being investigated in this study, sensing and intuitive learning styles. After having a final revision on the test, the reading comprehension test was conducted after the treatment process while the personality learning style questionnaire 
was distributed at the beginning of the study.

Prior to analyzing data for hypotheses testing, the researchers carried out homogeneity and normality testing as the fulfillment of statistical assumptions. The criteria of acceptance or rejection of the assumption was set at a level of significance .05 (95 percents confidence). The data used for the fulfillment of the statistical assumptions were the primary data obtained from the result of the reading comprehension posttest.
The result of the homogeneity testing analysis showed one of the observed significance level was lower than the level of confidence used in this study (Sig. .033 $>$ Sig. .05). Since the significance level that the researchers used was .05 $(95 \%$ confidence), it indicated that there was not enough evidence to accept the hypothesis that the data obtained from the two groups' variances were homogeneous. The result of the homogeneity testing of the variances is presented in Table 1.

Table 1. The Result of the Test of Homogeneity of Variances

\begin{tabular}{clcccc}
\hline No & \multicolumn{1}{c}{ Factors } & Levene Statistic & df1 & df2 & Sig. \\
\hline 1 & Teaching Strategies & .009 & 1 & 39 & .924 \\
2 & $\begin{array}{l}\text { Students' Personality } \\
\text { Learning Styles }\end{array}$ & 3.227 & 3 & 37 & .033 \\
\hline
\end{tabular}

The next step was examining normality of the data. The result of the analysis of the test of normality is presented in Table 2. The result showed that the observed significance values (zvalues) of the six sets of data obtained from the experimental and control groups' reading scores were greater than .05 (Sig. .193, Sig. .71, Sig. .134, Sig. .200, Sig. .200 , and Sig. $.200>$ Sig. .05 respectively). It means the data obtained from the posttest scores were normally distributed.

According to Erceg-Hurn and Mirosevich (2008), since one of the statistical assumptions was violated, non parametric statistical analyses-MannWhitney $U$ and Kruskal Wallis tests-to analyze the data was employed to examine the mean differences. The next step was testing the statistical hypotheses. To answer research problems, statistical hypotheses need to be established for statistical examination of mean differences. The first step to test the hypothesis was to establish the null hypothesis. The null hypotheses were formulated as follows: there is no difference in the students' reading comprehension taught by using the PQRST strategy and translation and reading aloud, there is no difference in the reading comprehension of students with the sensing style of learning and intuitive style of learning, and there is no interaction between the PQRST strategy and the students' personality learning styles. Alternative hypotheses were also formulated stating the reverse formulation of the null hypotheses.

Table 2. The Result of the Tests of Normality

\begin{tabular}{cccccccc}
\hline \multirow{2}{*}{ No } & \multirow{2}{*}{ Factor } & \multicolumn{3}{c}{ Kolmogorov-Smirnov ${ }^{\text {a }}$} & \multicolumn{3}{c}{ Shapiro-Wilk } \\
\cline { 3 - 8 } & Statistic & df & Sig. & Statistic & df & Sig. \\
\hline 1 & Experimental (PQRST) & .157 & 21 & .193 & .963 & 21 & .580 \\
2 & Control (Translation and & .134 & 20 & .200 & .957 & 20 & .484 \\
& $\quad$ Reading Aloud) & & & & & & \\
3 & Sensing - experimental group & .206 & 13 & .134 & .903 & 13 & .147 \\
4 & Intuitive - experimental & .219 & 8 & $.200^{*}$ & .915 & 8 & .388 \\
& group & & & & & & \\
5 & Sensing - control group & .157 & 11 & $.200^{*}$ & .961 & 11 & .788 \\
6 & Intuitive - control group & .180 & 9 & $.200^{*}$ & .938 & 9 & .561 \\
\hline
\end{tabular}


After the null and the alternative hypotheses were formulated, the last step was to conduct a test of statistical significance to accept or to reject the null hypotheses. The criteria of acceptance or rejection of the null hypotheses was a level of significance .05 (95 percents of confidence). It is acceptable to claim that the result is 95 percent correct as Ary, et al., (2006:179) suggested that .05 was acceptable in the field of education.

\section{FINDINGS AND DISCUSSION}

\section{The Posttest Results of the Experimental and the Control Groups}

The main data in this study were the students' reading comprehension scores of the experimental and the control groups obtained from the posttest. The posttest was carried out based on the schedule of Bahasa Inggris 1 and was also considered as a mid-term examination. All students of both groups took the posttest. Based on the analysis on the students' personality learning styles, the researchers found out that there were 13 students in the experimental group belonged to the sensing learning style and 8 of them belonged to the intuitive learning style. In the control group, 11 of the students belonged to the sensing learning style and 9 of them belonged to the intuitive learning style. The general summary of the result of the posttest analysis is presented in Table 4 .

Table 3. The Descriptive Analysis Summary of the Posttest Result of the Design

\begin{tabular}{|c|c|c|c|c|}
\hline $\begin{array}{l}\text { Teaching Strategy (A) } \\
\text { Personality } \\
\text { Learning Style }(\mathrm{B})\end{array}$ & & PQRST (A1) & & $\begin{array}{l}\text { ranslation and Reading } \\
\text { Aloud (A2) }\end{array}$ \\
\hline Sensing (B1) & $\begin{array}{l}\Sigma \mathrm{X} \\
\Sigma \mathrm{X}^{2} \\
\mathrm{X} \\
\mathrm{SD} \\
\mathrm{N}\end{array}$ & $\begin{array}{l}=820 \\
=672400 \\
=63.08 \\
=10.516 \\
=13\end{array}$ & $\begin{array}{l}\mathrm{X} \\
\Sigma \mathrm{X}^{2} \\
\mathrm{X} \\
\mathrm{SD} \\
\mathrm{n}\end{array}$ & $\begin{array}{l}=595 \\
=354025 \\
=54.09 \\
=11.14 \\
=11\end{array}$ \\
\hline Intuitive (B2) & $\begin{array}{l}\Sigma \mathrm{X} \\
\Sigma \mathrm{X}^{2} \\
\mathrm{X} \\
\mathrm{SD} \\
\mathrm{N}\end{array}$ & $\begin{array}{l}=475 \\
=225625 \\
=59.38 \\
=18.408 \\
=8\end{array}$ & $\begin{array}{l}\Sigma X \\
\Sigma X^{2} \\
X \\
\text { SD } \\
N\end{array}$ & $\begin{array}{l}=445 \\
=198025 \\
=49.44 \\
=17.579 \\
=9\end{array}$ \\
\hline Total & $\begin{array}{l}\Sigma \mathrm{X} \\
\Sigma \mathrm{X}^{2} \\
\mathrm{X} \\
\mathrm{SD} \\
\mathrm{n}\end{array}$ & $\begin{array}{l}=1295 \\
=1677025 \\
=61.67 \\
=13.723 \\
=21\end{array}$ & $\begin{array}{l}\Sigma \mathrm{X} \\
\Sigma \mathrm{X}^{2} \\
\mathrm{X} \\
\mathrm{SD} \\
\mathrm{n}\end{array}$ & $\begin{array}{l}=1040 \\
=1081600 \\
=52.00 \\
=14.179 \\
=20\end{array}$ \\
\hline
\end{tabular}

It was found out that the mean score of the experimental group was 61.67 while the mean score of the control group was 52.00. It could be concluded that the mean score of the experimental group was greater than that of the control group. The mean difference between the two groups was 9.67. Specifically, for the reading levels, the experimental group achieved higher scores in all five indicators tested than the control group. The detailed information of the means of the reading levels is presented in Table 4. 
Table 4. The Means of the Reading Levels of the Experimental (E) and Control (C) Groups

\begin{tabular}{lcccc}
\hline \multicolumn{1}{c}{ Content } & \multicolumn{2}{c}{ Literal } & \multicolumn{2}{c}{ Inferential } \\
\hline \multicolumn{1}{c}{ Indicators } & $\mathbf{E}$ & $\mathbf{C}$ & $\mathbf{E}$ & $\mathbf{C}$ \\
\hline $\begin{array}{l}\text { a. to deduce word meanings and use of } \\
\text { unfamiliar lexical items (words, } \\
\text { phrases, or sentences) }\end{array}$ & 80.00 & 66.00 & - & - \\
\hline b. to find explicit and implicit main ideas & 59.52 & 54.00 & 50.00 & 37.50 \\
\hline $\begin{array}{l}\text { c. to find details and specific information } \\
\text { from the text }\end{array}$ & 61.90 & 50 & 42.85 & 32.50 \\
\hline d. to identify pronoun referents & 80.90 & 72.00 & - & - \\
\hline
\end{tabular}

\section{Hypothesis Testing}

To answer the first research problem related to the effectiveness of the PQRST strategy in students' reading comprehension, the researchers applied Mann-Whitney $U$ test and the result of the inferential statistical analysis is presented in Table 5. The result showed that the observed significance level was lower than
.05 (Sig. .039 > Sig. .05). It showed that there was sufficient evidence to reject the null hypothesis that there was no difference in the students' reading comprehension taught by using the PQRST strategy and the Translation and Reading Aloud strategy. It meant the reading comprehension of the experimental and the control groups were statistically different.

Table 5. The Result of Mann-Whitney U Test

\begin{tabular}{cc}
\hline & reading comprehension score \\
\hline Mann-Whitney U & 131.500 \\
Wilcoxon W & 341.500 \\
Z & -2.060 \\
Asymp. Sig. (2-tailed) & .039 \\
\hline
\end{tabular}

To answer the second research problem related to the effectiveness of the PQRST strategy in reading comprehension of the students with the sensing style of learning and intuitive style of learning, the researchers used Kruskal Wallis test, which is a data analysis to test the mean difference of more than two groups if the statistical assumption (homogeneity or normality) was not fulfilled. The result of the analysis is presented in Table 6 .

Table 6. The Result of Kruskal-Wallis Test

\begin{tabular}{cc}
\hline & Statistics \\
\hline Chi-Square & 4.959 \\
df & 3 \\
Asymp. Sig. & .175 \\
\hline
\end{tabular}

The result of data analysis using the Kruskal-Wallis test showed that the significance value was .175. This significance level was greater than .05 (Sig. $.175>$ Sig. .05). It showed that although there were mean differences among the groups descriptively, the differences were not statistically significant. It implies that there was no sufficient evidence to accept the alternative hypothesis. In other words, there was no difference in the reading comprehension of students with the sensing style of learning and intuitive style of learning under the PQRST strategy and the translation and reading aloud strategy.

To answer the third research problem related to the interaction between teaching strategy and the students' personality learning styles, the researchers analyzed the data with the help of ANOVA as non parametric tests (e.g., Mann-Whitney and Kruskal-Wallis tests) do not provide an 
examination on interaction effects. The result of the analysis is presented in Table 7.

The result of the analysis showed that the significance value was .917. This significance level was greater than .05 (Sig.
$.917>$ Sig. .05). It showed that there was not enough evidence to reject the third null hypothesis, meaning that there was no interaction between teaching strategies and personality learning styles.

Table 7. The Result of Two-Way ANOVA

\begin{tabular}{lccccc}
\hline \multicolumn{1}{c}{ Source } & Type III Sum of Squares & df & Mean Square & F & Sig. \\
\hline Corrected Model & $1131.973^{\mathrm{a}}$ & 3 & 377.324 & 1.884 & .149 \\
Intercept & 126429.258 & 1 & 126429.258 & 631.129 & .000 \\
Personality & 172.538 & 1 & 172.538 & .861 & .359 \\
Strategy & 885.859 & 1 & 885.859 & 4.422 & .042 \\
Personality * strategy & 2.209 & 1 & 2.209 & .011 & .917 \\
Error & 7411.929 & 37 & 200.322 & & \\
Total & 141525.000 & 41 & & & \\
Corrected Total & 8543.902 & 40 & & & \\
\hline
\end{tabular}

\section{The Effectiveness of the PQRST Strategy in Teaching Reading Comprehension}

The result of the first hypothesis testing showed that there was a significant difference in the students' reading comprehension taught by using the The PQRST strategy compared to those taught using the translation and reading aloud strategy. It meant that the PQRST strategy was effective in making the quality of students' reading comprehension significantly better than those who were taught by using translation and reading aloud.

This finding supported the existing theory and other similar studies. It matches with the findings of a study conducted by Haeriyanto (2012) who conducted a classroom action research (CAR) in teaching reading comprehension for secondary school students using PQRST. The improvement of the students' reading comprehension was reflected in the gain score after implementing The PQRST strategy. The effectiveness of the PQRST strategy was also empirically supported by other studies other than English Language Teaching (ELT) fields. Miswadi, et al. (2010:563) conducted experimental research on secondary school students and found that The PQRST strategy was effective to improve the students' learning outcomes on one of chemistry topics, the atomic structures and periodic system of elements.

With aview to supports by theories and empirical evidence, there are several factors that are assumed to cause the effectiveness of PQRST in teaching the students reading compared to the translation and reading aloud strategy. First, according to Sulistyo, (2011:94-95), conceptually the PQRST strategy is one the teaching strategies which comprises of five stages/schemes - Preview, Question, Read, Summarize, and Test. It provides a step-bystep guidance to students prior, during, and after their reading process which is essential for their comprehension. Each stage gives benefits to students in facilitating their learning.

In the preview stage, the students were asked some basic questions related to the topic to activate their background knowledge. Then, they tried to find out the topic of the text by looking at a glance or by skimming over the text features including the title, figures, graphs, major headings, paragraphing, or the point in the reading text. From this activity, the students could obtain a general picture of what they learnt. It was in line with the theory mentioning that the benefits of previewing are giving the students the general picture of material being presented, 
helping them look for and recognizing the most important points, aiding them in seeing the organization of the subject matter, and forming the "big picture" of the material presented.

In the question stage, the students were asked to make questions as inquiry activities related to the topic or theme they had held in the previous activity. It was aimed at helping the students stay focused when reading. They could know exactly what to look for and focused on the important information when learning. These activities matched with what the theory states about the PQRST strategy that strategy encourages the students to watch for details when reading, helps them pay closer attention to what they read, increases their concentration by giving them something to hunt for their study, and enables them to spot more test questions.

In the read stage, the students read the passage carefully and reacted to what they read effectively. During the process of reading, they focused on processing the information and grasping the main ideas and details of the passage. While reading, they also jotted down some important points and difficult words in the passage. This stage has several advantages. They are preparing the students' mind to soak up knowledge, increasing the amount that can be learned, and decreasing study time. The next stage was the 'summarize' stage in which the students went over the main points of the information from the text by any means they can make, such as writing important pints, mind mapping, and making flowcharts. They summarized the passage individually or in groups. Through this activity, students could check on what they really learnt, demonstrating that they had a topic clearly in mind if they could put it into words, and removed doubts about how well they had learned the material.

In the test stage, the students looked back to the questions they constructed previously and answered them. If they got an unanswered question, they rewrote the question and tried to find several possible sources to find the answer. To ensure the students' comprehension, the students were asked to answer comprehension questions given by the teacher. The activities were aimed to check the students' understanding of the reading materials. The students could test themselves by thinking about the relevance of what they learnt and how it all fitted together and reviewed the materials and/or the teacher administered a reading comprehension test.

Second, schemes or stages in the PQRST strategy underline the constructivist nature of learning noting that reading is an active, often necessarily selective, effortful and iterative process (Johnston \& Anderson, 2005:13). The two experts also mention that techniques like PQRST work partly because they encourage use of some of the memory strategies alluded to above (Johnston \& Anderson, 2005:13). It could be seen from the teaching and learning process of this study. For example, when the students generated a question(s) to focus reading, they made an elaborative link between what is learnt wand what information is to look for.

Third, the PQRST strategy promotes 'deep' approaches to learning. Much research now shows that a student's broad 'approach' (including intention and strategy) to learning material has a strong influence on the outcome of learning (Johnston \& Anderson, 2005:10). They also highlight two aspects of deep learning. The first is a holistic, global attempt to understand the underlying core meaning of the material and the second is a much more localized, close attention to the detailed logic of the argument. It is different from surface approaches to learning which involve attempts to memorize information by rote. The weakness with rote learning is that it implies a passive reading or listening style. In this study, the PQRST strategy has been shown to give significant benefit to 
students, such as increasing the student's attempts to extract meaningful relationships within the material through the five stages.

Fourth, the PQRST strategy helped the students become motivated and actively participate in the teaching and learning process. As shown by the students' opinion during the treatment, most of the students in the experimental group enjoyed being taught with the PQRST strategy. This finding is supported by Nunan (1997) as cited in Oxford (2003:11) that in ESL/EFL studies, strategy instruction led to increase EFL learning motivation. Ehrman et al. (2003:320) also highlight that by providing students with learning experiences that meet their needs for competence, relatedness, self-esteem, and enjoyment, teachers can increase their students' intrinsic motivation

During the treatment process, when the students did the review stage and raised questions, they were given opportunities to formulate their own questions related to the topics being learned and to engage in an active search for information to find answers to their questions. It is highlighted by Williams \& Burden (1997:121) that predicted questions raised by the students can be categorized as initiating motivation in which students have strong reasons for reading the text. In addition, the teaching and learning process should emphasize that learning is not a matter or accepting and memorizing but is should involve the students to actively engage in any classroom activities (Arsana, 2012:140).

Based on theoretical and empirical bases, the PQRST strategy was more effective in helping the students achieve better comprehension compared with translation and reading aloud strategy but the result did not show the optimum criteria of effectiveness. It could be seen from the mean of the posttest of the experimental group which was 61.67. However, the mean obtained was still on the average level and it has not reached the excellent level.

Based on the researchers' experience during the treatment to the students, it was found out that in the first four meetings, most students spent more time constructing their own questions because they were never trained to do such activities before. Even, the researchers needed to give the exercise on worksheets as homework because they could only finish summarizing and or answering their own questions. It was thought that 100 minutes were not sufficient to complete doing the five stages in the PQRST strategy optimally. Based on the analyses of the data collected using the questionnaire, it was found out that 6 students stated that they found stages in the PQRST strategy confusing and time consuming. Further analyses showed that those students were the low achievers, namely students who scored less than 60 in the posttest in the experimental group. During the implementation of the treatment, the students' low English proficiency made the teaching and learning process run slowly. Johnston \& Anderson (2005:13) note that the downside of such schemes in the strategies like SQ3R and PQRST is that they are time-consuming for the learner, rendering them impractical at times. In addition, younger learners/low proficient learners especially may not be adept at generating suitable questions on which to focus with their reading.

\section{Effect of the PQRST strategy on Reading Comprehension of Students' Sensing and Intuitive Styles}

The result of the second hypothesis testing showed that there was no statistical difference in the reading comprehension of students with different personality learning styles taught by using the PQRST strategy and the translation and reading aloud. It means that the strategy was not effective in making the quality of students' with sensing learning styles significantly 
different compared to those with intuitive learning styles.

The literature on learning styles uses the terms learning style, cognitive style, personality type, sensory preference, modality, and others rather loosely and often interchangeably (Ehrman, et al., 2003:314). There are many findings related to learning styles and students' reading comprehension. Those findings show different results and in relation to this study, some support the findings of this study while some others do not.

The finding of the present study about an insignificant relationship between personality and reading comprehension is in agreement with the findings of Erton (2010), Bagheri \& Faghih (2012), and Naveh et al., (2011) which showed that there is not a significant statistical difference between personality traits (in this case the observed personalities were extrovert and introvert) of the learners and their reading comprehension. On the other hand, the results are in contradiction with studies conducted by Riding \& Cowley (2011) who found out that there was a significant relationship between personality (extroverts and introverts), sex, motivation, and reading comprehension.

The insignificant result might derive from several reasons. First, the students might be accustomed to having lectures from their previous English sessions such as using translation and reading aloud strategy that might affect the application of the PQRST strategy in addition to spending little time for reading and doing their tasks during the period of learning. It can be seen from the process of treatment in the experimental group. Some of the students like being taught by using the translation and reading aloud strategy when they are learning.

Second, there are eight different types of personality learning styles, and only two of them covered in this study, which are sensing and intuitive. The other personality learning styles were presumed to affect the result of this study as probably there were some of the students having other learning styles other than sensing and intuitive and these could not be controlled during the study. In addition, the various students' learning style could be one of the factors that did not support the findings as some students could have more than one combination of the types of learning styles.

Third, the students' English proficiency was low. It was shown by their difficulty in grasping the idea of the passages due to the lack of the components of language knowledge mastery (vocabulary, morphology, phonology, syntax, and discourse.

However, attempts were carefully made to control some variables that might interfere with the students' learning during the experimentation process. Some of the attempts were as follows: choosing the subjects that had about the same language proficiency and studied at the same department, teaching the two groups on the same day and one after another, implementing the same lesson plans, and giving the two groups the same learning facilities. There might be some factors that could not be controlled in the present study such as the students' motivation in studying in the department, background knowledge, and emotional maturity.

\section{Interaction between the Teaching Strategy and the Students' Sensing and Intuitive Styles}

The result of the third hypothesis testing showed that there was no interaction between the PQRST strategy and the students with different personality learning styles. As mentioned previously, the strategy was effective in making the quality of students' reading comprehension significantly better than those who are taught by using the translation and reading aloud. The result of the data analysis showed that the mean of the students' posttest score in the experimental group was 61.67 while in the control group was 
52.00. However, the mean scores of the reading comprehension of the students with the sensing learning style and intuitive learning style taught by using the PQRST strategy were not significantly different. The posttest score mean of the students with the sensing learning style was 63.08 while with intuitive learning style was 59.38. It meant that there was no difference in reading comprehension score between students with the sensing and intuitive learning style taught by using PQRST.

This finding did not support the existing theories and the result of previous studies. Theories and studies agree that earning styles and learning strategies are often seen as interrelated. Styles are made manifest by learning strategies (Ehrman et al., 2003-315). Oxford (2003:1) also notes that language learning styles and strategies are among the main factors that help determine how -and how well-students learn a second or foreign language. A study by Al-Hajaya \& Al-Khresheh (2012) supported the theory that the instructional strategies influenced the achievement of students with different learning styles.

The insignificant result of the interaction between the PQRST strategy and students' personality learning styles (sensing and intuitive) might derive from several reasons. First, the students might be accustomed to having lectures from their previous English teachers, such as using translation and reading aloud strategy that might affect the application of the PQRST strategy. Second, there are eight different types of personality learning styles, and only two of them covered in this study, which are sensing and intuitive. There were probably some of the students having other learning styles. Finally, the students' English proficiency was low. It was shown by their difficulty in grasping the idea of the passages due to the lack of the components of language knowledge mastery. Athough attempts to control some variables that might interfere during the experimentation process were already made, there might be some factors that could not be controlledin the present study such as the students' motivation in studying in the department, background knowledge, and emotional maturity.

\section{CONCLUSION}

The findings of this study show that the PQRST strategy was effective in the teaching of reading comprehension in that students who were taught by using the PQRST strategy achieved better scores in reading comprehension than those taught using translation and reading aloud. But, it was also found that there was no difference in the reading comprehension of students with different learning styles taught by using the PQRST strategy and translation and reading aloud strategy. Students with different personality learning styles who were taught by using the PQRST strategy did not achieve better scores in reading comprehension than those taught using translation and reading aloud. The last finding showed that there was no interaction between teaching strategies and personality learning styles. Thus, the significant achievement gained by the experimental group was only attributed to by the teaching technique implemented, which was the PQRST strategy. In addition, empirically the students' personality learning styles played no role in affecting the students' reading comprehension.

Based on the findings, the findings of this study have both theoretical and practical contributions to be considered as alternative and effective strategies to develop the teaching and learning of English. Theoretically, the findings reveal that this study is valuable in examining the effectiveness of the PQRST strategy on students' reading comprehension. The findings give more additional theory related to the use of the PQRST strategy in the area of reading comprehension.

Furthermore, the findings of this study practically contribute to English 
teachers/lectures, and future researchers. In the first place, for the English teachers and lectures, in the teaching of students of nonEnglish Department, they need to consider applying the PQRST strategy because the strategy has been shown to be effective in helping students achieve better reading comprehension.

Secondly, teachers who teach reading comprehension should draw their attention on students' individual differences and uniqueness especially from personality type's point of view and their learning styles. Teachers should also consequently be equipped with practical knowledge of learning styles. By knowing the learners' learning style, it is expected that teachers can accommodate the learners in their learning process.

Finally, the findings of this study recommended that further research is warranted. The number of participants in this study was not large enough to draw conclusive results and more participation would provide a broader review of the effectiveness of the PQRST strategy and its interaction with students' personality learning styles. Furthermore, this research study only took into account one dimension of learning style, sensing and intuitive. Therefore, further studies on other types of learning styles are highly recommended to provide additional knowledge regarding the effectiveness of certain learning strategies and factors influencing the learning itself. Besides, there is also a possibility to investigate the effectiveness of the use of the PQRST strategy in different areas of subject matters or courses and in different levels of study.

\section{REFERENCES}

Ary, D., Lucy, C.J., \& Sorensen, C. (2006). Introduction to research in education ( ${ }^{\text {th }}$ Edition). Belmont: Wardsworth.

Ahuja, P. \& Ahuja, G.C. (2007). How to read effectively and efficiently. New Delhi: Sterling.
Al-Hajaya, N. \& Al-Khresheh, T. (2012). The effect of cognitive learning stylebased reading program on the achievement of Jordanian freshmen English majors. International Education Studies, 5(3), pp. 235-246.

Aniroh, K. (2009). From English as a general school subject onto english as a medium for learning specific subjects: The need to shift in the teaching orientation. TEFLIN Journal, 20(2), pp. 169-179.

Arsana, I.W. (2012). Pengaruh strategi pembelajaran terhadap hasil belajar pendidikan kewarganegaraan siswa kelas V yang memiliki kecerdasan emosional dan gaya belajar yang berbeda di Kecamatan Rendang, Karangasem, Bali. Unpublished Dissertation. Malang: Graduate Program of State University of Malang.

Bagheri, M.S. \& Faghih. M. (2012). The relationship between self-esteem, personality type and reading comprehension of Iranian EFL students. Theory and Practice in Language Studies, 2(8), pp. 1641-1650

Brown, H.D. (2007). Principles of language learning and teaching $\left(5^{\text {th }}\right.$ Edition). White Plains: Pearson Education.

Cohen, A.D. (1996). Second language learning and use strategies: clarifying the issues. A revised version of paper presented at the Symposium on Strategies of Language Learning and Use, Seville, Spain, December 13-16, 1994. (Online),

(www.carla.umn.edu/strategies/resourc es/sbiclarify.pdf), accessed on December 17, 2012.

Ehrman, M.E. \& Oxford, R. 1990. Adult

Language Learning Styles and Strategies in An Intensive Training Setting. Modern Language Journal, 74 (3): 311-326.

Ehrman, M.E., Leaver. B.L, \& Oxford, R.L. (2003). A brief overview of 
individual differences in second language learning. System, 31, pp. 313-330.

Erceg-Hurn, D.M \& Mirosevich, V.M. (2008). Modern robust statistical methods: An easy way to maximize the accuracy and power of your research. American Psychologist, 63(7), pp. 591-601.

Erton, I. (2010). Relations between personality traits, language learning styles and success in foreign language achievement. Hacettepe Üniversitesi Eğitim Fakültesi Dergisi (H.U. Journal of Education), (Online) 38, pp. 115126

(http://www.efdergi.hacettepe.edu.tr/e nglish/abstracts/38/pdf/\%C4\%B0SMA $\%$ C4\%B0L\%20ERTON.pdf), accessed on February 5, 2013.

Fahim, M. (2012). Effects of critical thinking strategy training on male/female EFL learners' reading comprehension. English Language Teaching, 5(1), pp. 140-145.

Felder, F.M. \& Soloman, B.A. (1991). Index of learning styles. North Carolina State University. (Online), (www.ncsu.edu/effective_teaching/ILS dir/ILS-a.htm), accessed on January $3^{\text {rd }}, 2013$.

Haeriyanto, A.I. (2012). Improving the reading comprehension skills of the eleventh graders of MA Nurul Jadid Paiton Probolinggo through the PQRST strategy. Unpublished Magister Thesis. Malang: Graduate Program of State University of Malang.

Hamra, A. \& Syatriana, E. (2010). Developing a model of teaching reading comprehension for EFL students. TEFLIN Journal, 21(1), pp. 27-40.

Hutchinson, T., \& Waters, A. (1987). English for specific purposes. New York: Cambridge University Press.

Johnston, B., \& Anderson, T. (2005). Information literacy and study skills:
An overview of research for $L T$

Scotland. (Online),

(http://www.educationscotland.gov.uk/ Images/overview_of_researchv2_tcm4 -285566.pdf), accessed on February 5, 2013.

Lightbown, P.M., \& Spada, N. (1993). How languages are learned. Oxford: Oxford University Press.

Marrapodi, J. (2004). MYERS-BRIGGS

Type indicator in education:

implications for adult literacy learners. A Paper Presented in Partial Fulfillment Of the Requirements of Directed Study: MBTI in Education, June, 2004. (Online), (www.applestar.org/capella/MBTI\%20 in\%20Education.doc), accessed on December 14, 2012.

Miswadi, S.S., Wijayati, N., \& Farikhat, L.I. (2010). Pengaruh penggunaan metode preview, question, read, summarize, and test melalui pendekatan contextual teaching and learning terhadap hasil belajar kimia siswa SMA. Jurnal Inovasi Pendidikan Kimia, (Online) 4(1), pp. 557-565 (http://journal.unnes.ac.id/nju/index.ph $\mathrm{p} / \mathrm{JIPK} /$ article/view/1313), accessed on February 5, 2013.

Nation, I.S.P. (2009). Teaching ESL/EFL reading and writing. New York: Routledge.

Naveh, M.H., Kafipour,.R., \& Soltania, R. (2011). The relationship among extraversion tendency, vocabulary learning strategies, and reading comprehension of EFL undergraduates in Kerman Province. Studies in Literature and Language, 3(2), pp. 104-110

Oxford, R. L. (2003). Language learning styles and strategies: An overview. learning styles and strategies. Oxford, GALA. (Online), pp. 1-25 (http://files.fernandamunoz.webnode.e s/2000000401816e19114/_2003_Oxford_R._Lang. 
_learning_tyles_and_strategies.pdf), accessed on January 2, 2013.

Pfister, A. (2000). The effect of personality type of bilingual students on English reading performance in a computer driven developmental reading laboratory: Implications for educational leaders. Boston: The University of Boston.

Riding, R.J., \& Cowley, J. (2011). extraversion and sex differences in reading performance in eight-year-old children. British Journal of Educational Psychology, 56, pp. 8894.

Robinson, P.C. (1991). ESP today: A practitioner s guide. New York: Prentice Hall

Ronald, S. (2012). Breaking poor reading habits. (Online), (http://www.rocketreader.com/whitepa per/Breaking_Poor_Reading.php), accessed on January $7^{\text {th }}, 2013$.

Sadeghi, N., Kasim, Z.M., Tan, B.H., \& Abdullah, F.S. (2012). Learning styles, personality types and reading comprehension performance. English Language Teaching, 5(4), pp. 116-123.

Sulistyo, G.H. (2011). Reading for meaning. Malang: Pustaka Kaiswaran.
Sulistyo, G.H. (2012). Pemetaan kemampuan membaca pemahaman isi teks akademik berbahasa Inggris mahasiswa program studi non bahasa Inggris. Unpublished Research Report. Malang: Faculty of Letters of State University of Malang.

Taber, J. (2006). A brief history of ESL instruction: Theories, methodologies, and upheavals. (Online), (http://papersbyjoantaber.blogspot.com /2006/05/brief-history-of-eslinstruction.html), accessed on January $7^{\text {th }}, 2013$.

Williams, M., \& Burden, R. (1997). Psychology for language teachers. Cambridge: Cambridge University Press.

Wilson, K. (2010). Reading aloud in class is a complete waste of time. (Online), (http://kenwilsonelt.wordpress.com/20 10/10/14/reading-aloud-in-class-is-acomplete-waste-of-time-discuss/), accessed on January $7^{\text {th }}, 2013$.

Winarni, I., Setijono, P., Tabiati, S.E., Ratnawati, R., \& Sadtono, E. (2005). English for non-English Departments at Brawijaya University: How Essential? TEFLIN Journal, 16(1). 